\title{
OVERCOMING THE WEAKNESSES IN ȘUKŪK: TOWARD RISK-SHARING INSTRUMENTS IN ISLAMIC FINANCE
}

\author{
Abdul Karim Abdullah (Leslie Terebessy)*
}

\begin{abstract}
This article focuses on the near defaults of high profile șukūk and recommends strategies for preventing defaults in the future. Due to their large size, the near defaults of the 'mega' șukūk issued by the subsidiaries of Dubai World had a great impact on confidence in the global șukūk market. The defaults and near defaults dented the reputation of șukūk as securities that offer strong protection to investors. In order to restore investor confidence in Islamic structured finance, a paradigm shift is required in the way șukük are structured. There is a need to move away from structuring șukūk as bond-like, non-tradable instruments that mimic conventional (unsecured) bonds, and structure șukūk as asset-backed, tradable securities that enable genuine risk sharing, an essential characteristic of Islamic finance.
\end{abstract}

\section{Șukūk: An Introduction}

The Arabic term șukūk is the plural of șakk, meaning 'legal instrument', 'deed' or 'cheque'. It is the Arabic name for what is known in conventional banking as 'financial certificates', but more commonly refers to the Islamic counterpart of 'bonds'. In the mediaeval period of Islamic civilisation, șakk (which is cognate with the European root 'cheque', from Arabic șakk, via Persian chakk) stood for any document representing a contract or transference of rights, obligations or monies done in conformity with Islamic law.

In contemporary Islamic banking, the essence of șukūk lies in the concept of asset monetisation - the so-called 'securitisation' - which is achieved through the process of issuance of $s u k \bar{u} k$. Its great potential is in transforming an asset's future cash flow into present cash flow. Sukukk, which may be issued on existing as well as specific assets that may become available at a future date, are certificates that represent ownership of specific, revenue generating underlying assets. As owners of the underlying assets, sukūk holders are entitled to the revenues generated by the underlying assets, minus any legitimate deductions such as management fees. $S u k \bar{u} k$

* Abdul Karim Abdullah (Leslie Terebessy) is Assistant Research Fellow at IAIS Malaysia. 
are issued by way of securitisation, the process of converting illiquid, non-tradable assets into liquid, tradable securities. Some scholars stipulate that real assets such as buildings or land comprise at least 51 per cent of the portfolio of assets to be securitised. Other scholars take the view that receivables also qualify as assets for the purpose of securitisation. ${ }^{1}$

However, some șukūk defaulted outright. On 27 April 2009, Kuwait-based The Investment Dar (TID) missed a US\$100 million payment on its șuku k registered in Bahrain. ${ }^{2}$ TID, which claimed 50 per cent of British luxury carmaker Aston Martin in its portfolio of investments, had debts at that time amounting to nearly US $\$ 3.5$ billion. ${ }^{3}$ The default was followed by a dispute with Lebanon's Blom Bank. ${ }^{4}$ The Dar default was followed on 12 April 2010 by a failure to pay a distribution payment of US\$3.3 million, on a US\$200 million sukūk by another Kuwait company, the International Investment Group (IIG). The same company defaulted a second time on 12 July 2010, failing to pay US\$152 million due on another sukukk. The Saad Group of Saudi Arabia, which owns a stake in HSBC, ${ }^{6}$ and has been at the centre of fraud allegations, defaulted on a US\$650 million șukük. ${ }^{7}$ Texas-based East Cameron Gas Company, which issued a US-offering of șukuk worth US $\$ 165$ million backed by oil and gas assets, was another defaulter. Most prominent among the 'near defaults' were șukuk issued by Nakheel World, a subsidiary of Dubai World, owned by the Dubai government. ${ }^{8}$ Due to the extraordinarily large sums involved, the Dubai 'near defaults' had the greatest impact on the șukūk market.

Islamic rulings (ahkām) for the conduct of commercial activities (mu 'àmalāt) include the permissibility of trade (bay ), risk or profit and loss sharing in commercial enterprise, safeguarding of the public interest (mașlahah), fulfilment of contracts ( $u q \bar{u} d$ ), giving full measure in business transactions, documenting future obligations, the avoidance of gharar (excessive uncertainty) and ensuring that wealth circulates among all levels of society. Also included are the prohibition (nahy) of usury or ribā, gambling (maysir), hoarding (ihtikār), manipulating markets to raise prices, and producing (or trading in) pork or alcohol. Apart from these basic commands and prohibitions, the principle of original permissibility (ibāhah) applies. ${ }^{9}$ This means that a practice is permitted unless it is specifically prohibited by a definitive (qat $\left.{ }^{(} \bar{l}\right)$ text. In general, "[t]he realisation of benefit and the prevention of poverty and hardship are among the cardinal objectives of the economic and political agendas of the Islamic government". ${ }^{10}$

$S u k \bar{u} k$ certificates are issued by one party (the issuer) and subscribed to (purchased by) another party (șukukk holders). Șukūk-like conventional bonds - help channel surplus funds into areas where shortages may be experienced. The key difference between conventional bonds and șukūk is that bonds pay interest while șukūk pay

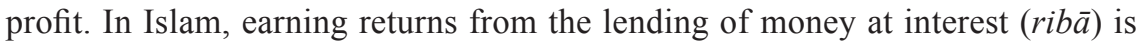
forbidden. Earning profit from trading or other business activity, by contrast, is not 
only permitted but encouraged. Profit can be earned through trading (distribution of goods and services) or by participating directly in the manufacturing of goods or the provision of services, public or private. Sukūk issued to finance the provision of goods and services provide opportunities for large numbers of people to participate in projects such as schools, hospitals, universities, clinics, factories, bridges, roads, ports, airports, highways and other enterprises. While the "focus of most sukuk offerings has historically been on real estate development projects and generally on acquiring real property $[\ldots]$ there is a recent trend towards new sectors such as energy, oil and gas, and renewable energy". ${ }^{.1}$

$S$ Sukuk are sometimes portrayed as "the Islamic and Shariah compliant alternatives to fixed income, conventional bonds and debt securities". ${ }^{12}$ This characterisation is only partly true. $S u k \bar{u} k$ and conventional bonds resemble one another in so far as both constitute means of raising and allocating funds in the capital markets. Yet they do so in different ways. In the case of $s u k \bar{u} k$, funds are raised by selling investment certificates to investors that signify proportionate ownership in an underlying asset, and entitle the holders of the certificates to a proportionate share of the profit generated by that asset or pool of assets. In the case of șuku $k$ issued to finance trade, this profit is fixed in advance. In case of the șuku $k$ issued to finance other activities, the profit varies according to market conditions. In the case of bonds, however, funds are raised in the form of interest bearing loans. With bonds, the principal amount of the loan has to be repaid on a specified date in the future, known as the maturity date. During the life of the bond, the issuers are obliged to make periodic payments of equal value (interest), determined in advance, to the bondholders. The issuer of a bond effectively borrows at interest from the buyers of the security. In the case of suk $\bar{u} k$, the incentive for investors to participate in business is a share of the profit. In the case of bonds, it is a fixed amount of interest, to be paid regularly, no matter how well - or poorly - the business being financed may perform. The relationship between the buyers (investors) and sellers (issuers) of șuku $k$ is one of partners. The relationship between the issuers and buyers of bonds is of a less equal nature, such as exists between creditors and debtors, where in most cases the creditors hold the upper hand.

$S u k \bar{k} k$ are issued to finance private or public enterprise, specifically trading and the provision of goods and services. Șukūk issued to finance trade appear to have the character of contracts of exchange ( 'uqūd mu 'āwad̄a $t$ ) while those issued to finance the production of goods and the provision of services take the form of contracts of participation ('uqūd ishtirāk). Both types pay profit rather than interest. All șukūk require assets "to be sold, leased, or invested in. This is the essence of sukuk [...] the certificate should represent an ownership interest in the underlying asset." ${ }^{\prime 3}$

In contracts of exchange (trade) șuku $k$ evidence a commitment by the sellers (issuers) of the șukuk to pay counterparties (which may be financial institutions) 
the cost of an asset plus a mark-up, from which comes the profit to the financial institution after expenses associated with the transaction have been paid. The payment is made on a deferred basis. Examples of this type are șukūk murābahah where payment is made on a deferred basis.

Investors can also participate in profit and loss sharing contracts by means of purchasing șukūk issued by partnerships, such as the mudārabah or mushärakah. Șukūk mushārakah and muḍārabah are risk (profit and loss) sharing investment participation contracts par excellence. Sukūk issued (and sold) to raise funds for purposes of participating in productive enterprise evidence the obligation on the part of the issuer to pay proportionate profits to the investors (suku $k$ holders). The amount of the dividends to be paid to investors (șkūk holders) out of total profits earned depends on a pre-agreed ratio of profit sharing, as well as on the efficiency of the assets purchased using the raised funds.

It has been noted that șukūk mud̄arrabah and mushärakah are similar to shares in conventional banking. Like ordinary shares, șukük enable risk sharing (although more so in the case of participatory contracts than in contracts of exchange). While there are some differences, for example those relating to voting rights, the mushärakah $s u k u \bar{k}$, the mudārabah șukūk, and conventional shares are all profit and loss sharing forms of participation in productive enterprise. Bona fide profit and loss sharing $s ̧ u k u k$ cannot default any more than ordinary shares can. The possibility of default in șukuk structured as genuine risk sharing securities in other words does not arise. There may be losses from time to time, and these have to be shared just as profits have to be shared, but there are no defaults. The fact that investors are exposed to the possibility of losses is in keeping with the profit and loss sharing principle of Islamic finance. The possibility of losses in risk sharing is, however, mitigated by the possibility and, indeed the prospect that profits, in particular over the longer term, will be greater than losses, if any. In other words, the great advantage of $s u k \bar{u} k$ mudārabah or mushärakah to issuers is that they are less risky to issuers precisely because the risk is shared with investors. Șukük mud̄arrabah and mushārakah in other words resemble equity financing: "equity financing is less risky in term of cash flow commitments. There is no obligation or liability to distribute or service profit when there is no profit made."14

Raising funds for financing activities other than trading can also take place by means of sale and leaseback of assets, known as șukük ijārah. Like șukūk murābahah, the ijārah is a sale contract, with the added features of a leaseback of the underlying assets by the investors to the originators. In șukūk ijārah, originators first sell specific assets to investors. The same assets are then leased back to the originators by the investors. At maturity, the assets are sold back to the originators by the investors (ssukuk holders). The initial sale of the assets to the investors enables the issuers to raise a lump sum of capital. The leaseback from the șukūk holders by 
the originator allows the payment of a regular and (in the short run) fixed stream of income (rent) to șukuk holders. The repurchase of the assets by the originators at maturity enables investors to recoup their principal amounts. Sukūk ijārah have been widely used, by both private sector companies as well as by governments to raise funds in the capital markets for a variety of purposes. ${ }^{15}$

The London Stock Exchange listed its first șukūk in July 2006. In part due to generous tax incentives, ${ }^{16}$ increasing numbers of non-Muslim institutions are raising capital by issuing șukük. Sovereign issues have declined in part as a result of difficulties experienced by countries such as Iceland, Spain, Greece and, most recently, Ireland. ${ }^{17} S u k \bar{u} k$ are also becoming popular in the United States. In 2009, General Electric became the first major US company to tap the șukük market, with a US $\$ 500$ million issue backed by revenues from its aircraft leasing business. ${ }^{18}$

Global issuance of $s u k \bar{u} k$ has been fuelled by rising revenues from the sales of oil. The main centres of trading of șukuk are Kuala Lumpur, Dubai, and London. Countries that issue both sovereign and corporate șukuk include the United Arab Emirates, Malaysia, Saudi Arabia, Qatar, the United Kingdom, Germany, Pakistan, the Philippines, and Indonesia. Since 2002, there have been "seven major types of sukuk and issuance in four currencies and by ten countries". ${ }^{19}$ Issuance has been growing on average by 20 per cent per year. ${ }^{20}$ In 2007, less than a year before the financial and economic crisis of 2008, a record of US\$31 billion șukük were sold globally. ${ }^{21}$ In 2008 , global issuance fell to US $\$ 14.9$ billion. ${ }^{22}$ Global issuance then rose to US $\$ 24.7$ billion in $2009 .^{23}$ In 2010 , global sales stood at US\$17.1 billion. ${ }^{24}$

\section{Securitisation}

$S u k \bar{u} k$ are products of securitisation, the process of transforming illiquid assets into marketable securities (liquid assets). A distinguishing feature of 'asset-backed' $s u k \bar{u} k$ is that $s u k \bar{u} k$ holders are paid dividends generated by underlying productive assets that also serve as collateral. These assets are either real (property), debts (financial receivables), or a combination of the two. Securitisation takes place as follows. The originator or party seeking to raise funds (the obligor) sells some of its assets to another company established specifically for the purpose of securitisation. This company is known as a special purpose vehicle (SPV) or a special purpose mudārib (SPM). It acts as a trustee on behalf of the șukūk holders and manages the assets and liabilities of the SPM for a specified period of time, independently of the sponsoring (originating) company. The SPM needs to be bankruptcy remote from the sponsoring company (originator) in order to protect șukuk holders from risks arising out of originator bankruptcy. When the SPM is bankruptcy remote from the originator, the investments of the șuku $k$ holders/buyers remain safe even if the originator (the company that sold the assets to the SPM) goes bankrupt. The 
originator cannot 'claw back' any assets it sold to the SPM in order to stave off a potential bankruptcy or to pay for any of its liabilities. ${ }^{25}$

The mudārib (SPM) next issues (and sells) șukūk to both local and foreign investors. The buyers of șukuk become the șukuk holders (investors). The proceeds of the sale of șukuk pay for the assets bought by the muda arib from the originator. The SPM remits dividends generated by the underlying assets periodically (twice a year) to the șukūk holders, less agreed-upon fees due to the mudāarib. ${ }^{26}$ Most șukūk - like bonds but unlike ordinary shares - come with maturity dates. On 'maturity date' the originators 'redeem' the sukük by repurchasing the underlying assets back from the șukuk holders, at a previously agreed upon price. This price is invariably the same as the price at which the assets were originally sold by the originator to the șuku $k$ holders (investors). The repurchase has the effect of returning to the șuku $k$ holders their initial investments.

In February 1988, the Fiqh Academy of the Organisation of Islamic Conference (OIC) declared that issuing and selling șukūk to investors, assuming the required conditions are met, is an acceptable and rib $\bar{a}$-free way of raising funds in the Islamic capital market. However, the following conditions, among others, need to be satisfied: "The Manager issuing Sukuk must certify the transfer of ownership of such assets in its (Sukuk) books, and must not keep them as his own assets."27 Moreover, șukuk assets must be "owned by the investors, who would have all the rights and obligations of ownership with respect to the underlying real assets". ${ }^{28}$ It needs to be emphasised that the claim embodied in sukūk is "not simply a claim to a cash flow but an ownership claim". ${ }^{29}$ The șukūk would "lose their Shari'ah compliance without a share in ownership of the asset"..$^{30}$

In practice, however, it became clear that "many companies do not want to 'sell' their quality assets to investors". ${ }^{31}$ As a result, most șukūk have been structured to enable originators to "legally retain" 32 ownership of the underlying assets. The control of the SPMs that purportedly act on behalf of the șukuk holders independently of the originators, has likewise in most cases remained with the originators. Accordingly, such SPMs can hardly be described as 'bankruptcy remote'. In still other cases, the underlying assets are not even sold to the mudârib (SPM) supposedly acting on behalf of the sukūk holders, but remain on the balance sheets of the originators. It would appear that "the assets in the structure are commonly for Shari'ah compliance only". ${ }^{33}$ As a result of this practice, in case of a bankruptcy of the originator, $s u k \bar{u} k$ holders would merely have the status of creditors rather than owners of the underlying assets. This produces a considerable degree of risk to șukuk holders.

\section{Asset-based and Asset-backed Șukūk}

$S u k \bar{u} k$ where the ownership of the underlying asset is transferred by way of a true sale to the sukük holders are known as 'asset-backed'. The "holder of an asset-backed 
sukuk is the owner of the underlying asset which behaves like collateral". ${ }^{34}$ When asset-backed șukuk are sold to investors in this way, the assets become bankruptcy remote. This means that the originator cannot 'claw back' any of the assets in case he goes bankrupt. Șukūk holders become the legal owners of the assets. The true sale and bankruptcy remoteness of the assets ensure that the șukük are truly 'backed' by assets: "if the originator defaults in its obligation, the sukuk-holders can dispose of [sell] the assets to third parties". ${ }^{35}$ Thus the investments of the șukūk holders are protected. Consequently, sukūk holders face less risk. Specifically, they face asset risk rather than originator risk. In case the underlying assets fail to pay expected dividends, șukūk holders can recover their initial investment by selling the underlying assets in the secondary market.

By contrast, with $s u k \bar{u} k$ where the sale of the underlying assets to the $s u k \bar{u} k$ holders is not a true sale, legal ownership of the underlying assets remains with the originators, or with an SPM controlled by the originators. With asset-based șukuk the ownership of the underlying assets is not legally transferred to the șukuk $k$ holders. The șukūk holders have only 'beneficial ownership' of the assets. ${ }^{36}$ 'Asset-based' $s u k \bar{u} k$ resemble conventional unsecured bonds, "similar to bonds that are not collateralized". ${ }^{37}$ Owners of asset-based șukūk thus face higher risk than owners of asset-backed șukuk . They face originator risk rather than asset risk.

Most șukūk "are 'asset-based', handing investors ownership of the cashflows but not of the assets themselves" ${ }^{38}$ Holders of the vast majority of sukūk "do not have proprietary rights but instead, beneficial ownership. The legal standing of investors is [...] akin to that of creditors." ${ }^{39}$ In insolvency proceedings, "sukuk [holders would] rank as creditors rather than equity holders". ${ }^{40}$ Rating agencies assign lower or no ratings to asset-based șukuk. Only " $30 \%$ of the sukuk issued have been rated" ${ }^{41}$ When they do assign a rating to asset-based $s$ un $\bar{k} k$, they assign it on the "creditworthiness of the issuer rather than the assets because of doubts over investors' claim to the assets". ${ }^{42}$

The difference between the asset-backed and asset-based șukūk may not be of much consequence so long as the underlying assets perform well for the șukuk holders (pay the promised dividends). The difference between asset-based and asset-backed sukūk, however, becomes crucial in the event of a default or a prospect of default by the originator, when the protection of the investments of the șukuk holders becomes an issue. In the case of asset-backed $s u k \bar{u} k$, the investments of the șukuk holders are protected because they are the legal owners of the underlying assets. The șukuk holders can sell the underlying assets - should the need arise - in the secondary market to recover their investments. In the case of asset-based $s u k \bar{u} k$, however, since legal ownership of the underlying assets remains with the originators, $s ̧ u k \bar{u} k$ holders are not able to sell the underlying assets because they do not legally own them. "Simply put, although the asset exists in asset-based sukuk structures, 
in default cases it does not provide protection to the sukuk-holders because they cannot sell it to third parties. ${ }^{43}$

Investors in 'asset-based' șukūk thus face the risk of losing their initial investment in toto. Not every șukūk investor appears to have realised this. A number of investors appear to have been under the impression that their șukuk "were 'asset-backed', giving them a claim on the assets in the event of a default". ${ }^{44}$ "In $90 \%$ of cases, that is incorrect." "A5 "Although linked to an underlying asset, most șuku $k$ are not secured instruments and should not be treated as such." ${ }^{46}$

While most șukuk have been asset-based, there have been notable exceptions. In the United Arab Emirates both Tamweel and Sorouh PJSC issued bona fide asset-backed sukūk. The ownership of the assets was fully transferred to the $s u k \bar{u} k$ holders, resulting in a legal ownership of the assets by the șukuk holders, rather than merely in 'beneficial' ownership. Such șukūk holders are exposed to asset risk rather than credit risk.

In the Tamweel asset-backed Sukuk, the freehold titles to approximately 1,000 properties are transferred to the Sukuk investors [șukük holders] along with the associated ljarah cash flows; these are the Sukuk assets. The property/land titles are registered in the name of the investors at the relevant land department. Any losses on those cash flows (that ultimately arise from the sale of distressed property) are passed on to sukuk holders, who are exposed to the asset risk. Even upon the insolvency of Tamweel, the assets will continue to pay the Sukuk investors. The Sukuk should survive. ${ }^{47}$

The purchase of the Tamweel asset-backed sukūk by investors had the character of a sale rather than a loan. The contract of sale of the underlying assets did not contain a repurchase agreement. Should the originators (issuers) wish to buy the underlying assets back from the șukūk holders, assuming the șukukk holders were willing to sell, it is unlikely that the originators would be able to buy the assets back from the suku $\bar{k}$ holders at the same price at which the originators sold them in the first place. It is unlikely that șukuk holders would sell the assets back to the originators at less than market prices, as under normal circumstances, market prices tend to rise over time, particularly in the case of real estate. If the șukuk holders were to sell the assets back to the originators at the same price at which they bought them, suk $\bar{u} k$ holders would forgo any gains they may have been able to obtain from the appreciation in the market value of the assets.

\section{Bond-like Characteristics of Islamic Securities}

There is no doubt that adverse economic conditions contributed to the defaults and near defaults. However, the fact that șukuk - apart from not paying interest - were structured to have "bond-like characteristics" also played a role. ${ }^{48}$ Despite 
outward compliance with the shari 'ah, "much of Islamic finance today is focused on replicating the conventional system [...] an inevitable consequence is that any problems/flaws are also likely to be replicated (emphasis added)." ${ }^{49}$

Not only were sukūk structured to imitate bonds; the vast majority (90 per cent) were structured to mimic conventional unsecured bonds (asset-based șukūk). In other words, the overwhelming majority of suku $k$, were not collateralised. ${ }^{50}$

[M]any sukuk are structured to resemble conventional bonds, meaning the risks of ownership are transferred to the issuer rather than shared by the investors [...]. This is one of the criticisms of Islamic products: instead of coming up with products that reflect the spirit and substance of Islamic law, they are structured very similar to conventional products. ${ }^{51}$

Sukūk ijārah in particular are customarily structured to resemble conventional bonds. The bond-like features of șuku $k$ are commonly justified by saying that the "market tends to [...] expect sukuk to be within the 'fixed income' types of investment with minimal or controlled risks and capital preservation features". ${ }^{52}$ The "market participants [...] expect sukuk to behave like conventional bonds in terms of capital preservation, periodic distribution frequency and rate of return, and [to possess] any other additional investor protection mechanisms like the ability to take collaterals and credit enhancements". ${ }^{53}$

Among features that imparted to șukuk the character of conventional bonds was the undertaking ( $w a^{\prime} d$ ) by issuers to repurchase the underlying assets from the investors at par value, on a specified maturity date in the future. ${ }^{54}$ The repurchase undertaking ( $\mathrm{wa}^{\prime} \mathrm{d}$ ) is at bottom little more than a way to "repay principal to the Sukuk investors". ${ }^{55}$ By obliging issuers to repurchase the underlying assets on the maturity date of the $s u k \bar{u} k$, the arrangers of $s u k \bar{u} k$ (banks or other financial institutions), effectively create an "amount owing" by issuers to șukūk holders. ${ }^{56}$ This replicates for issuers a risk similar to that facing issuers of conventional bonds, the risk of default. The risk takes the form of a possibility that by the time the suku $k$ 'mature', issuers might not have enough money to repurchase the underlying assets from the suku $k$ holders. ${ }^{57}$ This risk is more precisely known as the asset redemption risk. ${ }^{58}$ Asset redemption risk arises "due to the fact that the originator has to buy back the leased assets". ${ }^{59}$ It occurs when the originator does not have enough capital "to buy [the underlying assets] back from the certificate holder". ${ }^{60}$

While the repurchase undertaking ( $\mathrm{wa}^{\prime} \mathrm{d} d$ ) is advantageous to the investors in that it "guarantees" them a repayment of their original investment on a specified date in the future, the need to repurchase the underlying assets imposes an obligation on issuers to ensure that they have sufficient sums of money ready to redeem the $s u k \bar{u} k$ by the time they mature. The requirement to repurchase the underlying assets effectively transforms what should be a profit and loss sharing relationship 
in the first place - a partnership (mushārakah or mudārabah) - into a creditor/ debtor relationship.

Șukūk have other features "in common with conventional fixed income or 'debt' instruments". ${ }^{61}$ Sukūk agreements are characterised by an absence of a provision to share losses. They promise only profits. Moreover, the quantum of these profits is fixed in advance. By right, profits should fluctuate according to the profitability of the underlying assets, as is the case with all risk sharing securities. The payment of fixed returns, without any provision for sharing losses, is a distinguishing characteristic of conventional, interest-bearing bonds.

The commitment to pay predetermined dividends without requiring investors to share losses, mitigates much uncertainty for the suppliers of capital. It provides them with a contractual certainty of earning 'profits' - specified in advance and in isolation from the efficiency of the underlying assets. At the same time, it absolves the investors from any responsibility to share any losses. The promise to pay predetermined dividends, generated in an uncertain business environment, amounts to promising contractual certainty (of profits) on the basis of operational uncertainty. Such an agreement appears rather lopsided and can thus hardly be viewed as a genuine risk-sharing partnership.

The twin practices of refunding to investors their capital by 'repurchasing' the underlying assets (redeeming the șuku $k$ ) and paying pre-determined dividends to $s ̧ u k \bar{u} k$ holders without requiring them to share any losses, "created sukuk instruments that, in substance, attempt to be identical to conventional bonds". ${ }^{22}$ While șukük may have achieved shari 'ah compliance in form, it is less certain that they achieved it in substance. "Questions have been raised as to whether mirroring existing products and returns through financial engineering is a sound basis for the industry to develop [...]. Islamic finance differentiates itself from other forms of finance through the sanctity of the shariah principles on which it is based [...]. If this sanctity is compromised, then the point of Islamic finance is lost." ${ }^{63}$ For these and other reasons, "The AAOIFI Sharia Board recommends and advises Islamic financial institutions to limit their dependence on operations which closely replicate traditional lending and borrowing, and to capitalize on real musharakah transactions based on profit and loss sharing, in a way that better achieves Shariah objectives." ${ }^{94}$

The recommended form of business participation in Islam is the partnership, in the form of the mudārabah or the mushärakah. "Mudharabah may be viewed as equity due to its feature of no pre-fixed periodic payments; rather payments are made from profits, similar to dividends. Further, as a general rule, the rab al-mal cannot foreclose or take legal action if there are no profits for distribution." ${ }^{65}$ "Unlike interest-based transactions in which the profit is predetermined, fixed and essentially non-speculative, in the profit-sharing transactions envisaged by 
the Shari ${ }^{\prime} a h$, the profit level remains undetermined and generally predicated on speculative risk-taking." ${ }^{\circ 6}$

\section{Advantages of Risk Sharing}

"Risk-taking [is] integral to the Islamic modes of commerce such as mudarabah and musharakah." ${ }^{67}$ When sukūk are structured as bona fide risk sharing, asset-backed $s u k u \bar{k}$, the possibility of default does not arise. There may be losses, but there are no defaults. "If Shariah principles are to be adhered to", the originator or obligor need not pay șukūk holders when there are "no profits to be distributed". ${ }^{68}$

Risk sharing securities such as common shares (equity), unlike interest bearing debt securities, do not commit issuers to pay profits without regard to the performance of the underlying assets. ${ }^{69}$ Much less do they commit issuers to pay only profits whose magnitude, moreover, is specified in advance. Profits by definition depend on the efficiency of the underlying assets generating them. The prospect that suku $\bar{k}$ structured as profit and loss sharing instruments may fail to pay dividends in itself should not be cause for alarm, as the possibility of incurring losses is balanced by the prospect of earning profits. ${ }^{70}$

With șukūk designed as profit and loss sharing securities, the requirement to share risk automatically mitigates against overinvestment, as business plans with limited prospects of success will attract few investors. Buyers are more likely to exercise care when investing in risk sharing securities, because they know that they agree to share not only profits but also losses: "investors need to conduct a thorough analysis and due diligence of the underlying assets themselves before they take the decision to invest". ${ }^{71}$ The experience of pension funds, insurance companies, hedge funds and investment banks, that suffered multi-billion dollar losses in the recent financial crisis despite the fact that they purchased 'AAA' rated securities, has shown that it is risky to rely on the assessments of rating agencies alone.

The profit and loss sharing character of $s u k \bar{u} k$ reduces the likelihood that issuers (sellers) of șuku k will raise funds in excess of what is needed to finance viable business proposals. This increases the stability of the issuer and, by extension, of the capital market in which risk sharing securities are extensively utilised. The utilisation of risk sharing securities distributes risk more widely throughout the system, and thus reduces overall exposure for everyone. It also provides a strong incentive to all parties to do what they can to ensure that their respective counterparties remain stable, as all share a common fate. In order to raise funds, issuers of profit and loss sharing (PLS) șukukk need to convince investors that potential profits on the $s u k u \bar{k} k$ being offered significantly outweigh potential losses. Business proposals with prospects of success should face little difficulty in attracting sufficient liquidity. By contrast, business proposals with poor prospects will attract few investors. The 
expanded use of PLS șukūk will thus contribute not only to greater stability of the financial system, but also to a more efficient allocation of capital and the reduction of waste.

The fact that risk sharing șukuk do not come with guarantees does not mean that holders of such securities cannot recover their investments. Depending on timing and market conditions, holders of risk sharing securities can liquidate their holdings in the secondary market. S $u k \bar{u} k$ would, however, first have to be structured as asset-backed rather than asset-based securities. "Backing by real assets ensures that a Sukuk is tradable." ${ }^{.72}$ Backing șukūk by assets would bring the added advantage of stimulating trading in the secondary markets, which are known to be sluggish under the current regimen.

While structuring securities in sharì 'ah compliant ways may not guarantee profits, it does guarantee doing business in ethical and sharì ah compliant ways. Since all business carries risks, there can never be a guarantee of profits any more than there can be a guarantee against losses. Bona fide risk sharing instruments do not come with predetermined and 'guaranteed' profits, 'maturity periods', or 'refunds' of shareholders' capital. These are characteristics of conventional, interestbearing bonds, structured to minimise, if not eliminate, most risks facing creditors. Instead of being structured as risk sharing securities, conventional interest-bearing bonds are structured as risk-shifting instruments, which means that they effectively transfer nearly all risk to the borrowers. Among recent manifestations of this trend is the introduction of variable 'profit rate' housing loans, in which home buyers pay variable amounts on their monthly instalments over the lifetime of the loan, depending on the movements of a benchmark, such as the Base Lending Rate (BLR), to which the 'profit rates' on those loans are pegged. The practice of pegging or benchmarking protects financial institutions from increases in the costs of their own borrowings. These costs may rise due to increases in the rate at which financial institutions borrow from other institutions, such as the interbank rate. The interbank rate in turn is pegged to the Bank Rate, which is the rate at which the central bank may lend funds to financial institutions as the need arises. While passing on the risk of increases in current interest rates to homeowners may be comforting to financial institutions, it produces a considerable degree of uncertainty to the borrowers, as it means that they never know in advance what amount they may be asked to pay in any given month, with little prior notice.

\section{Dubai World}

Between January 2006 and December 2007, before the economic and financial crisis of 2008, Dubai companies issued numerous sukūk. In January 2006, PCFC of Dubai issued $\$ 3.52$ billion convertible mushārakah șukūk, guaranteed by Dubai 
World, to fund DP World's acquisition of P\&O, the UK's biggest ports and ferries operator, the third largest in the world. ${ }^{73}$ Dubai World also purchased the Turnberry golf course and a 21 per cent interest in the London Stock Exchange. In December 2006, Nakheel World, a subsidiary of Dubai World, issued US $\$ 3.5$ billion șukūk. This was soon followed by an additional US\$750 million of sukūk. In addition, Jebel Ali Free Zone issued US\$2 billion, and Dubai World US\$1.5 billion worth of suku $k .{ }^{74}$ In 2007, Dubai World purchased the luxury liner Queen Elizabeth 2.

In October 2008, as the global financial crisis was gripping the rest of the world, Dubai announced an ambitious US\$38 billion development plan, that included the tallest tower in the world. In the run up to the global financial crisis Dubai World and its investment arm, Istithmar purchased a number of 'trophy properties' that included:

CityCenter Casino \& Resort, a large Las Vegas development in which Dubai World teamed with MGM Mirage. Dubai World's share of the CityCenter investment was \$5.4 billion [...]. Barneys, the luxury retailer, bought in 2007 for $\$ 942$ million; 450 Lexington Ave. [...] in Manhattan, bought for $\$ 600$ million in 2006; a stake in the Mandarin Oriental, a 248-room hotel in Manhattan [...] in 2007 [...] at \$380 million; and a 50\% stake in the Fontainebleau Miami, an 876-room resort hotel in Miami [...] for $\$ 750$ million [and] the iconic art-deco former Adelphi hotel building on the Strand, WC2. ${ }^{75}$

By the end of 2009, Dubai World and its companies accumulated debt of over US $\$ 100$ billion to over 100 lenders. ${ }^{76}$ Its debts currently exceed its GDP. ${ }^{77}$ Publicly, Dubai "acknowledges having US $\$ 80$ billion of liabilities". ${ }^{78}$ US $\$ 50$ billion of its liabilities are scheduled to mature by $2013 .{ }^{79}$ The United Arab Emirates has a population of 4.5 million and is smaller than South Carolina.

The credit squeeze and a 50 per cent drop in oil prices in 2008 from their peak levels ended a six-year boom, fuelled in part by high oil prices. Sales, profits and asset prices all declined. Property prices likewise dropped 50 per cent from their pre-crisis peak in 2008. In Saudi Arabia the stock market lost up to two thirds of its market capitalisation. "Cheap money, leverage and expectations of ever-rising property prices generate 'hot money inflows' which ultimately reverse in spectacular fashion when the bubble bursts." ${ }^{\circ 1}$ According to several reports, funds from doubtful sources helped fuel the boom. ${ }^{82}$ In early 2008, "authorities embarked on a series of high-profile corruption investigations at some big real-estate and finance firms". ${ }^{83}$

The șuku $k$ market "has not escaped the throes of the credit crisis $[\ldots]$ with investment banks and finance houses worldwide still reeling from the collapse of the U.S. sub-prime mortgage market and the breakdown of the wholesale money markets amid persistent counterparty risk concerns and deep-seated investor distrust in credit-sensitive assets" ${ }^{84}$ Since the crisis started, approximately US $\$ 430$ billion of planned development projects, the majority of them in Dubai, have been cancelled..$^{85}$ 
Poor investment decisions contributed to the problems. ${ }^{86}$ "Many of the high profile sukuk defaults have taken place as the result of poor business decisions, not Shariah. ${ }^{" 87}$ With the onset of the economic and financial crisis in 2008, the market for luxurious properties weakened. In 2009 oil prices fluctuated between US\$35 to US\$80 per barrel. Sales and rentals of properties slowed. There was not enough demand for the newly constructed facilities to generate the income necessary to pay off all the commitments on a timely basis.

Real estate prices have collapsed and are now only half of what they were a year ago. And yet new villas and luxury condominiums are still being completed every day - and are standing empty. Entire floors are deserted in the skyscrapers along Sheikh Zayed Road, and giant banners with the words 'To Let' are displayed across the fronts of buildings. Real estate experts estimate that only 41 percent of office space is occupied, and the vacancy rate is only expected to increase. In 2011, Dubai, a city of about 1.5 million, will have more office space available than Shanghai, which is 10 times as large as Dubai. ${ }^{88}$

In the first half of 2009 Nakheel, which issued șukūk guaranteed by Dubai World but not the Government of Dubai, declared a loss of US $\$ 3.65$ billion. This compared to a profit of US\$722 million during the same period a year earlier. Losses were attributed to slower sales and write-downs in the values of properties. ${ }^{89}$ On 22 February 2009 the Abu Dhabi-based central bank of the United Arab Emirates bought US $\$ 10$ billion of sukūk from Dubai. ${ }^{90}$ Two banks backed by the Government of Abu Dhabi bought another US\$5 billion of Dubai World bonds..$^{91}$ In October 2009 , one month before the call for a standstill on șukūk issued by Nakheel, Dubai sold an additional US $\$ 2.5$ billion of sukūk.

When the economic downturn came, sales and rentals of newly constructed waterfront residential and commercial properties did not generate enough revenue to redeem the assets underlying US\$4.1 billion worth of șukuk, the largest ever issued, which matured on 14 December 2009. On 25 November 2009, in a 200 word statement, Dubai World announced that it was seeking six additional months to repay \$26 billion of maturing liabilities, including the US\$4.1 billion Nakheel sukūk due on 14 December 2009. The announcement sent shockwaves through the global financial markets, raising fears of default on sovereign debt, ${ }^{92}$ and triggered an extensive capital flight. "Credit-rating agencies quickly downgraded all governmentrelated debt. ${ }^{\circ 93}$

The subscribers (buyers) of the șukūk issues comprised both foreign and local investors. A refusal to grant a standstill or restructuring would trigger default and formal bankruptcy proceedings. Such proceedings would have been complex due to the fact that a number of the șuku $k$ agreements lacked clarity regarding the rights and obligations of the counterparties. Even though Muslim scholars certified the sukūk as sharī'ah compliant, there was the (sharì' ah) risk that, 
a contract might unexpectedly be declared incompatible with sharia law and thus invalid - a risk heightened by the absence of a single, worldwide body to set standards for sharia compliance. Investors also often think they own the assets involved in a sukuk but may only own the right to the cashflow from the assets - a crucial difference in a default. ${ }^{94}$

Few laws exist in Dubai to govern bankruptcy proceedings: "the prospect of losses has forced creditors to think about some of the uncertainties surrounding Islamic default. One issue is enforceability: many sukuk contracts are governed by English law but refer to assets located in the Gulf." 95 Investor confidence has been damaged in the wake of "uncertainty about investor protection". 96

Many investors assumed that the debts were "backed by the government of Dubai, and ultimately by Dubai's oil-rich neighbour, Abu Dhabi". ${ }^{97}$ On 30 November 2009, however, the Government of Dubai announced that it did not guarantee the debts of Dubai World. This prompted fears that its creditors could lose billions of dollars. "Many creditors had assumed that the structure of Islamic bonds implied there was state backing for this type of financing." 98

In a television interview on the same day, the director-general of the Department of Finance, Abdul Rahman al-Saleh, announced that lenders to Dubai World were in for "short-term pain". "Creditors need to take part of the responsibility for their decision", he stated. "The government is the owner of the company, but since its foundation it was established that the company is not guaranteed by the government." "These announcements "reminded investors that tacit sovereign guarantees may be worthless". ${ }^{100}$ Nakheel șukük promptly fell to 38 cents on the dollar. ${ }^{101}$ Following the announcements, "fears surfaced that sukuk failed to provide the same legal protection as conventional bonds [...]. The concern is that sukuk creditors may not be protected." 102 Holders (buyers) of șukūk realised that they had a "limited ability to lay their hands on their assets". ${ }^{103}$ There was uncertainty as to whether the $s u k \bar{u} k$ holders would be legally able to take possession of assets underlying the securities in a time of distress.

With English and American law one can predict the outcome but there is more uncertainty in Dubai as there has never been a major corporate insolvency [...]. The issues could be heard in an English court if the relevant documentation allows it but enforcement might have to take place in Dubai. There is no precedent for this kind of eventuality. The system has not been tested. ${ }^{104}$

Because șukuk were subject to overlapping regulatory jurisdictions (of the sharī ah in Muslim countries and conventional law in non-Muslim countries), it would be difficult to take possession of the underlying assets.

It became apparent that UAE law places restrictions on foreigners dealing in sukuk, and while it's true that the sukuk market is governed by English law, and comes under the 
jurisdiction of the British court system, the enforcement of this requires the consent of the UAE authorities. This means that sukuk holders are at the mercy of sukuk issuers, limiting their legal options [...]. ${ }^{105}$

On 14 December 2009, just hours before US\$4.1 billion of $s u k \bar{u} k$ was due, Abu Dhabi announced a US\$10 billion loan to Dubai. ${ }^{106}$ In March 2010, Dubai presented another rescue plan of US\$9.5 billion. On 20 May 2010 Dubai World announced that it reached agreement with a group of creditors to restructure US $\$ 23.5$ billion of liabilities.

The 97 creditor banks of Dubai World include four British banks, HSBC, Lloyds, RBS, and Standard Chartered. Others include the Bank of Tokyo-Mitsubishi, Abu Dhabi Commercial Bank and Dubai's Emirates NBD bank. These seven banks hold 60 per cent or US\$14.1 billion of Dubai World's debt. ${ }^{107}$ "Lenders will wait up to eight years to get their US\$14.4 billion back but have avoided a 'haircut' on their principal under the terms of the deal, which offers 1 percent cash interest and an extra 1.5-2.5 percent per annum rolled up into a lump sum payment on maturity." 108

\section{Conclusions and Recommendations}

During the recent economic crisis stock and property markets fell in the Gulf countries just as they had declined in the rest of the world. All markets experienced reduced growth, lower asset prices and reduced liquidity.

Structuring $s u k \bar{u} k$ to resemble conventional bonds brought into being a new type of risk, the asset redemption risk which is analogous to the risk of default on conventional bonds. The asset redemption risk does not arise in relation to risk sharing instruments, because they do not oblige issuers to refund the initial amounts invested. Investors are free to recover their investments by selling their suku $k$ in the secondary market. When losses are experienced by issuers of PLS instruments, they declare a 'loss', and the loss has to be absorbed by the șukūk holders. In times of distress there are no defaults, only losses.

The requirements to 'repay' the initial amounts raised (and to pay pre-determined dividends) committed issuers to provide contractual certainty on the basis of an uncertain economic environment. By agreeing to these terms, investors exposed themselves to the asset redemption risk, and thus to the possibility that issuers might not be able to redeem the underlying assets by 'repurchasing' them on their respective due dates.

There is a need to structure $s u k \bar{u} k$ as bona fide risk sharing instruments rather than as securities that mimic conventional bonds. Another pitfall to avoid is accumulating excessive debt, as during recessions the costs of servicing the sukuk may exceed the returns generated by the underlying assets. The assets could most probably 
be liquidated only at steep discounts during a time of distress, thus resulting in additional losses to issuers.

- Sukūk geared to raise funds for investment need to be structured as profit and loss sharing (PLS) instruments. This will prevent the possibility of default.

- There is a need to structure all șukūk as 'asset-backed' in order to enhance investor protection, and make the șukūk tradable. This will eliminate the asset redemption risk. It will also make the șukük tradable in the secondary market.

- Transparency in șukūk issuance needs to be enhanced. Șukūk need to state clearly whether they are asset-backed or only asset-based. Lack of transparency in issuance may well amount to a form of gharar.

- Issues of overlapping jurisdictions need to be resolved.

\section{Notes}

1. Rafe Haneef, "From 'Asset-Backed' to 'Asset-Light' Structures: The Intricate History of Sukuk", ISRA International Journal of Islamic Finance 1, no. 1 (December 2009), 111-12.

2. Kuwait issuances of $s u k \bar{u} k$ took place offshore, as Kuwait had no șukūk or trust laws in place.

3. "Crisis and Opportunity", The Economist, 28 May 2009, available online at http://www.economist. com/node/13751652 (accessed on 20 September 2010).

4. The bank sued Dar in a British court for US\$10.7 million and 5 per cent it claimed in unpaid yearly dividends. Despite the fact that Dar's sharī 'ah advisors declared the transaction legitimate, Dar refused to pay on the grounds that the wakālah contract was not sharí 'ah-compliant because it contained a commitment to pay 'fixed' returns that resembled interest. See Mushtak Parker, "Dar Chief Comments Give Creditors Hope", Arab News.Com, 16 August 2010, available online at http://arabnews.com/economy/islamicfinance/article103429.ece (accessed on 11 September 2010).

5. Mushtak Parker, "Sukuk Defaults Turn Spotlight on Sukuk Governance", Arab News.Com, 8 August 2010, available online at http://arabnews.com/economy/islamicfinance/article97957. ece (accessed on 11 September 2010).

6. Carl Mortished, "Nakheel Debt Talks Turn Spotlight on Future of the Islamic Bond Market", The Times, 12 November 2009, available online at http://business.timesonline.co.uk/tol/business/ industry_sectors/construction_and_property/article6913156.ece (accessed on 7 October 2010).

7. Anouar Hassoune, "Sukuk It Up", The Economist, 15 April 2010, available online at http://www. economist.com/node/15908503 (accessed on 17 September 2010).

8. Only 25 per cent of the securities issued by Dubai companies were in the form of șukuk. The rest were conventional interest-bearing bonds.

9. Mohammad Hashim Kamali, Islamic Commercial Law: An Analysis of Futures and Options (Kuala Lumpur: Ilmiah Publishers, 2002), xii.

10. Ibid., 210.

11. Mohamed Ridza Abdullah, "Regulator Issues: Innovations and Application in Sukuk", in: Abdulkader Thomas (ed.), Sukuk (Kuala Lumpur: Securities Commission Malaysia, Sweet and Maxwell Asia, 2009), 83.

12. Securities Commission Malaysia, The Islamic Securities (Sukuk) Market (Petaling Jaya [Malaysia]: LexisNexis Malaysia, 2009), 10 and 24.

13. Imran Mufti and Sema Kandemir, "Exotic Sukuk Features", in: Thomas (ed.), Sukuk, 278.

14. Securities Commission Malaysia, The Islamic Securities (Sukuk) Market, 14. 
15. A distinguishing feature of șukük ijärah as they are commonly structured is that the sale of the underlying assets by issuers (originators) to the șuku $k$ holders (investors) is not a 'true' sale. This means that the legal ownership of the assets remains with the originators and is not transferred to $s u k \bar{u} k$ holders. Investors (șukuk holders) acquire merely what is known as 'beneficial' ownership. 'Beneficial' ownership, a concept that originates in common law, bestows on an 'owner' merely the use of a property, but not its legal ownership. In an ijārah structure, after 'buying' specified assets from the originator, the 'beneficial' owner in turn 'rents' the same assets to their legal owner, the originator.

16. Profits on șukūk issued by companies registered in offshore tax-free zones are exempt from most taxes, including income taxes, although stamp duties need to be paid.

17. In Greece, "public debt is expected to reach $130 \%$ of GDP by the end of 2010"; see Willem Buiter, "Polite Suggestion to the Dubai Sovereign that Creditors of Dubai World not Be Bailed out", Financial Times, 27 November 2009, available online at http://blogs.ft.com/maverecon/2009/11/ polite-sugggestion-to-the-dubai-sovereign-that-creditors-of-dubai-world-not-be-bailed-out/ (accessed on 21 July 2010).

18. Tom Hundley, "Will Dubai Be a Drag on Gulf Region?" The New York Times, 26 January 2010, available online at http://www.nytimes.com/2010/01/27/business/global/27dubai. $\mathrm{html}$ ? pagewanted=2\&_r=1\&sq=sukuk\&st=cse\&scp=1 (accessed on 16 July 2010).

19. Rodney Wilson, "How Expansive are the Frontiers", in: Thomas (ed.), Sukuk, 335.

20. Philip Bowring, "Malaysia's Next Big Thing", The New York Times, 1 December 2009, available online at http://www.nytimes.com/2009/12/02/opinion/02iht-.html?scp=4\&sq=sukuk\&st=cse (accessed on 16 July 2010).

21. Suryani Omar, "Malaysia Insurers Hindered by Lack of Sukuk: Islamic Finance", The Star [Kuala Lumpur], 11 January 2011, http://www.bloomberg.com/news/2011-01-10/malaysia-insurershindered-by-lack-of-sukuk-islamic-finance.html (accessed online on 12 January 2011). See also Anousha Sakoui, "Sukuk: Sustained Recovery Expected in Second Half of the Year", Financial Times, 12 May 2010, http://www.ft.com/cms/s/0/3c123094-5c91-11df-bb38-00144feab49a.html (accessed on 21 July 2010).

22. Malaysia Islamic Financial Center, "Sukuk Overview", 12 January 2011, available online at http:// www.mifc.com/index.php?ch=menu_foc_suk\&pg=menu_foc_suk_over (accessed on 12 January 2011. See also Querubin J. Minas, "Islamic Finance Gaining Momentum", Saudi Gazette, 29 November 2010, available online at http://www.saudigazette.com.sa/index.cfm?method=home. regcon\&contentID=2010112788066 (accessed on 29 November 2010).

23. n.a. "The Importance of the Islamic Sukuk Market", Islamic Financial Industry News Centre: Gulf Press, 4 January 2011, http://www.cibafi.org/newscenter/english/Details.aspx?Id=11352\&Cat=0 (accessed on 12 January 2011).

24. Suryani Omar, "Malaysia Insurers". See also n.a. "The Importance".

25. The 'clawing back' of assets can only happen when the șukük are structured as asset-based rather than asset-backed.

26. Assets of SPMs may include ports, factories, telecommunication businesses, schools, hotels, hospitals, clinics, highways and residential or commercial properties. Sometimes an SPM owns and manages a single asset along with the permit to operate it, such as a power plant. Liabilities include payments to purchasers of $s u k \bar{u} k$.

27. Accounting and Auditing Organization for Islamic Financial Institutions (AAOIFI), available online at http://www.aaoifi.com/aaoifi_sb_sukuk_Feb2008_Eng.pdf (accessed on 7 September 2010).

28. Wilson, "How Expansive", 353.

29. Mohammad Hashim Kamali, "A Shari' ah Analysis of Issues in Islamic Leasing”, Journal of King Abdul Aziz University 20, no. 1 (2007), 12-13.

30. Ibid., 16. 
31. Khalid Howladar, "The Future of Sukuk: Substance over Form?" CPI Financial, 31 May 2009, available online at http://www.cpifinancial.net/v2/fa.aspx?v=0\&aid=260\&sec=Islamic\% (accessed on 28 July 2010).

32. Ibid.

33. Ibid.

34. Natalie Schoon, "Basel II and Sukuk", in: Thomas (ed.), Sukuk, 124.

35. Shabnam Mokhtar, "Function of Wa'd in Asset-Backed Sukuk", ISRA Bulletin 4 (December 2009), 7.

36. Schoon, "Basel II and Sukuk", 114. "In reality [...] ownership under Shariah documentation is only beneficial ownership and does not translate into actual ownership over the sukuk assets (emphasis added)" (Harun Kapetanovic and Muhamed Becic, "Mudharabah Sukuk: Essential Islamic Contract, Applications and Way Forward", in: Thomas (ed.), Sukuk, 231. The concept of 'beneficial ownership' means the ability to use or derive a benefit from an asset, without legally owning it. The concept is found in English law, and is alien to the shari 'ah. Beneficial ownership confers on the "owner" the right merely to use a property rather than legal ownership. Thus a 'beneficial owner' cannot sell 'his' property because it actually belongs to someone else, in our case, the originator. Transferring merely 'beneficial ownership' to șukūk buyers enables obligors to avoid the payment of stamp duties and asset sales taxes.

37. Schoon, "Basel II and Sukuk", 124.

38. Hassoune, "Sukuk It Up".

39. Securities Commission Malaysia, "Mega Sukuk Defaults: Acid Test for Islamic Finance?" Malaysian ICM 4, no. 4 (December 2009), available online at http://www.sc.com.my/eng/html/ icm/0912_msianicm.pdf (accessed on 7 October 2010), 1, 3-7.

40. Ibid., 6 .

41. Jamal Abbas Zaidi, "Nature of Risks Present in Sukuk Structures: Rating Agency Perspective", in: Thomas (ed.), Sukuk, 322.

42. AsiaoneNews, "Dubai Debt Woes Give Islamic Finance its First Big Crisis", asiaoneNews, 2 December 2010, available online at http://www.asiaone.com/News/Latest+News/Business/Story/ A1Story20091202-183596.html (accessed on 13 October 2010).

43. Mokhtar, "Function of Wa'd", 7.

44. Hassoune, "Sukuk It Up".

45. Ibid.

46. Rahail Ali, "Legal Certainty for Sukuk", in: Thomas (ed.), Sukuk, 104.

47. Howladar, "The Future".

48. Shabnam Mokhtar, Saad Rahman, Hissam Kamal, and Abdulkader Thomas, "Sukuk and the Capital Markets", in: Thomas (ed.), Sukuk, 19.

49. Howladar, "The Future".

50. Securities Commission Malaysia, The Islamic Securities (Sukuk) Market, 49. See also, Anouar Hassoune, "The Meaning of Ratings for Islamic Financial Institutions", Islamic Finance News 7, no. 26 (30 June 2010), 17-18.

51. AsiaoneNews, "Dubai Debt".

52. Securities Commission Malaysia, The Islamic Securities (Sukuk) Market, 24.

53. Ibid., 24.

54. Requiring șukūk holders to sell the underlying assets back to the originators at the same price at which they were initially purchased is disadvantageous to the șuku $k$ holders. It deprives them from realising any capital gains that underlying properties, especially real estate such as residential and commercial properties, which are commonly used in șukük ijärah, would likely have registered in normal times. Any profits realised from capital gains could well be higher than the total paid out to the șukük holders in the form of rental payments, when șukük holders lease the assets back to the originators.

55. Howladar, "The Future".

56. Securities Commission Malaysia, "Mega Sukuk Defaults". 
57. The sums involved were in a number of cases very large. Admittedly, had economic conditions been more favourable, issuers of șukūk may well have been able to meet their obligations. If repurchase agreements were to be an integral part of the șukuk structure, it would have been better to repurchase the underlying assets from the șukuk holders via amortisation. Even though the periodic 'coupon' payments would have been larger on account of including portions of the principal, there would have been no pressure on issuers to have a large sum of capital ready at the end of the maturity period of each $s u k \bar{u} k$, to repay $s u k \bar{u} k$ holders the principal amounts 'owed' to them.

58. The asset redemption risk is similar to the risk of default that characterises conventional bonds. 'Default' signifies a failure to make a promised payment or payments by debtors to creditors. No pressure to pay fixed payments or to 'repay' the principal exists on issuers of profit and loss sharing contracts.

59. Tony Rhodes (ed.), Euromoney Encyclopedia of Debt Finance (London: Euromoney Books, 2006), 132.

60. n.a., "Risks Underlying Sukuk", FinancialIslam.com, available online at http://www.financialislam. com/risks-underlying-sukuk.html (accessed on 12 October 2010).

61. Howladar, "The Future".

62. AsiaoneNews, "Dubai Debt".

63. Zarina Anwar, "The Emerging Islamic Capital Market", in Thomas (ed.), Sukuk, 6.

64. Accounting and Auditing Organization for Islamic Financial Institutions (AAOIFI).

65. Kapetanovic and Becic, "Mudharabah Sukuk", 227.

66. Kamali, Islamic Commercial Law, 209.

67. Ibid., 209-10.

68. Securities Commission Malaysia, "Mega Sukuk Defaults", 1, 3-7.

69. The so-called 'preferred shares' combine various features of shares and bonds. Preferred shares are senior to common shares but subordinate to bonds. If dividends are declared, they must be paid to holders of preferred shares before they are paid to holders of common shares. Like bondholders, holders of preferred shares have no voting rights.

70. In a sound business venture, total profits will generally be higher over the longer term than total losses, thus enabling the company to grow and prosper.

71. Ayman H. Abdel-Khaleq and Todd Crosby, "Musharakah Sukuk: Structure, Legal Framework, and Opportunities", in Thomas (ed.), Sukuk, 206.

72. Lowells Group, "Islamic Finance, Shariah, Sukuk \& Securitisation", 2004, available online at http://yasaar.org/.../20177\%20Islamic\%20finance\%20client\%20note1.pdf, (accessed on 13 October 2010), 10.

73. Muhammad Ayub, Understanding Islamic Finance (Hoboken NJ: John Wiley and Sons Ltd, 2007), 389.

74. Lahem al-Nasser, "Is Sukuk Fever Over?" Asharq Alawsat, 17 April 2010, available online at http://aawsat.com/english/news.asp?section=6\&id=20605 (accessed on 26 July 2010).

75. David H. Jones and Andrew V. Petersen, "A Dubai World Debt and Nakheel Sukuk: Apocalypse Now? Distressed Real Estate Alert”, $K \& L$ Gates, 10 December 2009, available online at http:// www.klgates.com/newsstand/Detail.aspx?publication=6066 (accessed on 21 October 2010).

76. "Dredging the Debt", The Economist, 29 October 2009, available online at http://www.economist. com/node/14753834 (accessed on 19 September 2010).

77. Mortished, "Nakheel Debt".

78. “A Financial Sandstorm", The Economist, 30 November 2009, available online at http://www. economist.com/node/15004072 (accessed on 19 September 2010).

79. Beat Balzli, Alexander Jung, and Bernhard Zand, "Dubai's Debt Woes Unsettle Financial World", Spiegel Online International, 30 November 2009, available online at http://www.spiegel.de/ international/world/0,1518,664225-2,00.html (accessed on 17 September 2010). 
80. Abeer Allam, “Al Rajhi Turns to Untapped Sukuk", Financial Times, 4 May 2010, available online at http://www.ft.com/cms/s/0/77d7767a-5714-11df-aaff-00144feab49a.html (accessed on 21 July 2010).

81. AsiaoneNews, "Dubai Debt Woes".

82. In the course of money-laundering investigations in 2007, the Central Bank of the United Arab Emirates discovered accounts in "major Dubai-based banks that have enormous balances yet have been ostensibly set up by fathers for their sons at university, or by tour guides, shopkeepers, used-car salesmen and perfume vendors, all with official salary statements of less than $\$ 1000$ per month $[\ldots]$ later that year, a Sharjah national who was a member of the Central Bank's investigation team had his house attacked by suspected Russian money launderers, while an Indian member of the team began to receive death threats" (Christopher Davidson, "Dubai: The Security Dimensions of the Region's Premier Free Port", Middle East Policy Council, available online at http://www. mepc.org/journal/middle-east-policy-archives/dubai-security-dimensions-regions-premier-freeport (accessed on 12 September 2010)).

83. Chip Cummins, Stefania Bianchi, and Mirna Sleiman, "Dubai: A High Rise, Then a Steep Fall", Wall Street Journal, 5 December 2009, available online at http://online.wsj.com/article/ SB125988807548075805.html?KEYWORDS=sukuk (accessed on 6 October 2010).

84. Heiko Hesse, Andreas Jobst, and Juan A. Sole, "Islamic Securitization: The Right Way Forward?" Roubini Global Economics, 13 February 2009, available online at http://www.roubini.com/ financemarkets-monitor/255550/islamic_securitization_-_the_right_way_forward (accessed on 9 October 2010).

85. Cummins, Bianchi, and Sleiman, "Dubai".

86. Development in Dubai included the construction of the world's tallest building and 40,000 yet to be completed luxury (up to 7,000 square feet) homes on three man-made islands, shaped like palm trees. It also includes the construction of more than 100 luxury hotels, inclusive of several seven-star hotels, and a ski slope in the Mall of the Emirates. Nakheel, the subsidiary of Dubai World built 'The World', a cluster of 300 islands shaped like the world, offshore of Dubai. One of the palm islands is to have a 7.5-mile long string of luxury homes on stilts, shaped like a poem written by Dubai's head of state, Sheik Mohammed bin Rashid Al Maktoum, which reads in part, "It takes a man of great vision to write on water" (Cummins, Bianchi, and Sleiman, "Dubai").

87. Yusuf Talal deLorenzo, chief sharì $a h$ officer at Shariah Capital, at a recent Islamic finance forum at the George Washington University Law School, hosted by the US-Qatar Business Council, in Barbara Ferguson, "Forum Discusses Nuances of Islamic Finance, Arab News.Com, 8 August 2010, available online at http://arabnews.com/economy/article97934.ece (accessed on 11 September 2010). The forum was co-hosted by the Arab Bankers Association of North America and the National Council for US Arab Relations.

88. Balzli, Jung, and Zand, "Dubai's Debt".

89. Elena Moya, "Six Dubai Companies Downgraded to Junk Status", The Guardian, 8 December 2009, available online at http://www.guardian.co.uk/business/2009/dec/08/dubai-companiesdowngraded-rating-action (accessed on 10 August 2010).

90. Haris Anwar, "Dubai Bonds to Rally as Default Risk Wanes, Deutsche Bank Says", Bloomberg Businessweek, 23 June 2010, available online at http://www.businessweek.com/news/2010-06-23/ dubai-bonds-to-rally-as-default-risk-wanes-deutsche-bank-says.html (accessed on 14 July 2010).

91. Abu Dhabi, at the head of the Emirates, controls 7 per cent of global and 90 per cent of the Emirates' oil resources.

92. Sakoui, "Sukuk".

93. "Standing Still but Still Standing", The Economist, 26 November 2009, available online at http:// www.economist.com/node/14977157 (accessed on 19 September 2010).

94. "Suckers for Sukuk? Have Dubai's Troubles Exposed Fatal Flaws in Islamic Finance?" The Economist, 16 April 2010, available online at http://www.economist.com/node/15924217 (accessed on 19 September 2010).

95. Hassoune, "Sukuk It Up". 
96. Heiko Hesse and Andreas Jobst, "Debriefing Nakheel: Wider Implications for the Sukuk Market", Roubini Global Economics, 29 April 2010, available online at http://www.roubini.com/emergingmarkets-monitor/258811/debriefing_nakheel_-_wider_implications_for_the_sukuk_market (accessed on 9 October 2010).

97. "Default Lines: What Would Happen if a Member of the Euro Area Could No Longer Finance its Debt?" The Economist, 3 December 2009, available online at http://www.economist.com/ node/15016124 (accessed on 19 September 2010).

98. David Robertson, "Investors Face Huge Losses as Debt-Ridden Dubai World is Abandoned by Government", The Times, 30 November 2009, available online at http://business.timesonline. co.uk/tol/business/industry_sectors/banking_and_finance/article6937612.ece (accessed on 7 October 2010).

99. Sarah Arnott, "Gulf State Turns Its Back on Dubai World's $\$ 59$ Billion Debt", The Independent, 1 December 2009, available online at http://www.independent.co.uk/news/business/news/gulfstate-turns-its-back-on-dubai-worlds-59bn-debt-1831758.html (accessed on 10 August 2010).

100. "A Financial Sandstorm".

101. Ainsley Thomson, "The Calculus Behind Nakheel's Repayment", Wall Street Journal, 29 March 2010, available online at http://webcache.googleusercontent.com/search?q=cache:if6yZwTIO18 J:online.wsj.com/article/SB10001424052702303429804575149842965628952.html+\%22The+ Calculus + bahind + Nakheel $\% 27 \mathrm{~s}+$ Repayment $\% 22 \& \mathrm{~cd}=1 \& \mathrm{hl}=\mathrm{en} \& \mathrm{ct}=\mathrm{clnk} \& \mathrm{gl}=$ my $($ accessed on 4 October 2010).

102. Carl Mortished, "Western Investors Watch Nervously as Worth of Islamic Bond is Tested", The Times, 27 November 2009, available online at http://business.timesonline.co.uk/tol/business/ markets/the_gulf/article6934074.ece (accessed on 7 October 2010).

103. Usman Hayat, "Islamic Finance's Sukuk Explained", Financial Times, 11 April 2010, available online at http://www.ft.com/cms/s/0/cec38bf2-440b-11df-9235-00144feab49a.html (accessed on 9 July 2010).

104. Phil Abbott, in: Edward Fennell, "Dubai's Golden Sands Lose their Lustre", The Times, 10 December 2010, available online at http://business.timesonline.co.uk/tol/business/law/ article6950725.ece (accessed on 8 October 2010).

105. Lahem al-Nasser, "The Impact of Law on Religious Rulings", Asharq Alawsat, 20 July 2010, available online at http://aawsat.com/english/news.asp?section=6\&id=21634 (accessed on 26 July 2010).

106. Cassell-Bryan Low and Andrew Critchlow, "Dubai World Promises but the Damage May be Done", Wall Street Journal, 15 December 2009, available online at http://webcache.googleusercontent.com/search?q=cache:7umGH95VBKYJ:online.wsj.com/article/SB1000142405274870 3954904574596013729588066.html+Dubai+World+Promises, + but + the + Damage + May + Be + D one\&cd $=1 \& \mathrm{hl}=$ en \&ct $=$ clnk\&gl=my (accessed on 4 October 2010$)$.

107. Reuters, "Dubai May Launch Dollar Sukuk This Year-Bankers", Asharq Alawsat, 26 July 2010 , available online at http://aawsat.com/english/news.asp?section=6\&id $=21309$ (accessed on 26 July 2010).

108. "Dubai World in \$23.5 Debt Deal with Banks", Arab News.Com, 21 May 2010, available online at http://arabnews.com/economy/article55913.ece (accessed on 13 September 2010). 